\title{
Moderating Variable Dalam Konsep Contingency dan Peran Mediating Effect dalam Perusahaan
}

Cahyo Adityo Irawan

s130118033@ubaya.student.ac.id

Contingency theory merupakan penelitian yang mengadopsi pendekatan kontingensi yang bertujuan untuk memahami dampak strategy orientation terhadap kinerja UKM dalam konteks tehnological turbulence dinamis. Teori kontingensi tersebut muncul untuk mengkritik teori manajemen klasik karena teori tersebut mengabaikan faktor kontingensi. Menurut kontingensi bahwa baik teori birokrasi dari Max Weber maupun teori manajemen ilmiah dari Frederic Taylor terlalu fokus pada internal organisasi. Premis dasar dari teori kontingensi yaitu bahwa perusahaan mencapai kinerja terbaiknya ketika struktur perusahaan relevan untuk menangani kontingensi yang terlalu dipaksakan oleh ukuran, teknologi, dan lingkungan mereka. Teori kontingensi ini bertujuan untuk memahami bagaimana perusahaan membuat kinerja yang diharapkan dengan lingkungan bisnis internal dan eksternal berjalan selaras. Teori kontingensi berpandangan bahwa lingkungan eksternal merupakan determinan utama dari kinerja perusahaan. Sebagai organisasi, perusahaan menerima pengaruh dari lingkungan bisnis. Secara khusus, teori ini menekankan pada pertanyaan tentang apakah variabel kontingensi berkontribusi pada kinerja perusahaan. Oleh karena itu, perusahaan tidak hanya perlu memperoleh dan mengembangkan sumber daya mereka tetapi juga perlu meningkatkan kemampuan untuk menghadapi turbulensi yang terjadi di lingkungan. Perusahaan dianggap sebagai organisasi berbasis kontingensi ketika dapat beradaptasi dengan lingkungan bisnis, seperti pilihan domain pasar produk untuk menangani masalah kewirausahaan, inovasi untuk menangani masalah teknik, dan kemampuan untuk mengurangi ketidakpastian untuk mengatasi masalah administrasi. (Pratono, 2016)

Upaya untuk menjelaskan penerapan konsep teori kontingensi perlu menggunakan moderating variable. Teknologi informasi didefinisikan sebagai moderating variable yang menawarkan nilai bisnis teknologi. Teknologi informasi dapat meningkatkan kinerja ketika perusahaan dapat menyatukan faktor organisasi yang lain dengan baik termasuk strategy orientation. Teknologi sering kali didefinisikan sebagai variabel moderasi yang menciptakan kinerja perusahaan melalui faktor organisasi seperti itu, yang dipahami sebagai pelengkap 
sumber daya. Investasi di bidang TI memungkinkan UKM untuk memperoleh informasi tentang kebutuhan pelanggan, yang dapat mengingatk an perusahaan akan pasar baru dan perkembangan teknologi menjadi nilai bisnis. Berbeda dengan penelitian sebelumnnya, penggunaan financial leverage sebagai moderating variable yang digunakan untuk mengukur rasio total kewajiban terhadap total aset perusahaan dan implikasi strategis yang berdampak negatif pada CSR dan kinerja keuangan. Financial leverage berperan penting untuk memperingatkan manajer dalam pengambilan keputusan. Financial leverage tidak hanya mempengaruhi CSR tetapi juga dapat mempengaruhi jaminan pihak ketiga (TPA). Financial leverage memiliki dampak langsung terhadap kapasitas sumber daya perusahaan dan kombinasi CSR dan TPA yang dapat mengurangi kendala yang ditimbulkan oleh lingkungan alam dan meningkatkan profit. Penelitian ini menyatakan bahwa financial leverage memoderasi hubungan antara CSR dan kinerja keuangan (ROA dan ROE), tetapi financial leverage tidak memiliki hubungan statistik dengan jaminan pihak ketiga dan tidak dapat memoderasi hubungan antara CSR dan jaminan pihak ketiga. (Oware \& Mallikarjunappa, 2019)

Penelitian lainnya menggunakan quality management sebagai moderating variable. Quality management atau manajemen kualitas memainkan peran moderasi dalam hubungan antara manajemen lingkungan dan produktivitas tenaga kerja dalam perusahaan. Pengalaman dari manajemen kualitas dapat membantu mengurangi beban dari investasi manajemen kualitas dan proses transformasi, meningkatkan efisiensi karyawan dalam situasi ketika para karyawan menangani masalah lingkungan, dan mengurangi dampak negatif dari manajemen lingkungan terhadap produktivitas tenaga kerja secara keseluruhan. Mempertimbangkan efek dari manajemen kualitas, perusahaan harus menerapkan metode dan pengalaman manajemen mutu yang canggih dalam manajemen lingkungan agar mendapatkan hasil yang lebih baik (Ma, Zhang, \& Yin, 2019)

Efek mediasi (Mediating effect) merupakan efek dampak dari suatu hubungan yang kompleks. Berbagai tingkat dampak orientasi kewirausahaan pada keunggulan kompetitif berkelanjutan perusahan membutuhkan penyelidikan lebih lanjut dengan variable mediasi untuk menjelaskan suatu hubungan. Efek mediasi berperan untuk menjelaskan efek suatu hubungan dalam kinerja perusahaan. Efek mediasi secara positif menghasilkan kontribusi bagi kinerja perusahaan. Ada beberapa efek mediasi yang memiliki dampak langsung yang positif bagi kinerja perusahaan. 
Kepercayaan sangat penting untuk mempromosikan bentuk organisasi adaptif, seperti membangun hubungan jaringan sosial dan mengurangi penipuan yang merugikan. Ada beberapa jenis mediating effect dari suatu hubungan. Pertama, Kepercayaan secara positif memediasi hubungan antara struktur jaringan sosial dan kinerja perusahaan. Kinerja penjualan membutuhkan kemampuan perusahaan untuk membangun kepercayaan konsumen. Perusahaan yang mengikat jejaring sosial dengan pelanggan akan dapat mengembangkan kepercayaan di pasar online, sedangkan mereka yang kurang mengenal jejaring sosial cenderung kurang percaya pada pemasaran online. Lalu, Kepercayaan secara positif juga memediasi hubungan antara struktur jaringan sosial dan kemampuan penjualan. Perkembangan jaringan sosial memungkinkan konsumen untuk mengunjungi pasar online secara teratur dan membangun kepercayaan. Kapabilitas penetapan harga merupakan bagian dari kapabilitas pemasaran yang penting bagi perusahaan untuk mencapai kinerja yang maksimal. Perusahaan yang berhasil mendapatkan kepercayaan pelanggan cenderung berkembang secara adaptif. Kemudian kepercayaan secara positif juga memediasi hubungan antara struktur jaringan sosial dan kemampuan harga. Kemampuan menjual mengacu pada sejauh mana perusahaan dapat mengelola penjualan berbagai macam produk ke pelanggan yang sudah ada. Perusahaan yang semakin bergantung pada sumber eksternal pemasok dan mitra memiliki lebih banyak peluang untuk mencapai kinerja inovatif yang lebih baik. (Pratono, 2018)

Selain itu ada juga efek mediasi dari kapabilitas penjualan dan penetapan harga. Kemampuan menjual secara positif memediasi hubungan antara jejaring sosial struktur dan kinerja perusahaan. Kemampuan penetapan harga bergantung pada kinerja penjualan. Di bawah ketidakpastian pasar yang tinggi, opsi untuk mengubah jaringan sangat penting untuk kinerja perusahaan. Lalu, kemampuan menjual secara positif memediasi hubungan antara jejaring sosial struktur dan kemampuan harga. Perusahaan dengan harga premium harus mampu secara ekonomi untuk sepenuhnya menjaga kepercayaan dan kapabilitas harga dalam konteks hubungan sosial. Bagi perusahaan yang mengandalkan ritel online, kemampuan penetapan harga menentukan kinerja perusahaan. Kemampuan menjual secara positif juga memediasi hubungan antara kepercayaan dan harga. Kemampuan penetapan harga menunjukkan kemampuan perusahaan untuk menetapkan harga yang dapat mempengaruhi nilai pelanggannya. Dari efek mediasi penetapan harga, kemampuan penetapan harga secara positif memediasi hubungan antara jaringan sosial struktur dan kinerja perusahaan. Kemampuan perusahaan untuk menangani 
struktur jaringan sangat penting untuk menangani berbagai tingkat konflik. Kemampuan penetapan harga secara positif memediasi hubungan antara kepercayaan dan kinerja perusahaan. Perusahaan dengan kemampuan menjual menyadari bahwa banyak produk mampu menghasilkan beberapa tingkat peluang penjualan. Di bawah persaingan harga yang tinggi, persepsi keadilan sangat penting bagi penjual, yang mungkin mengalami distribusi pembayaran yang kurang adil. Kemampuan penetapan harga secara positif juga memediasi hubungan antara kemampuan menjual dan kinerja perusahaan. (Pratono, 2018)

\section{References}

Ma, Y., Zhang, Q., \& Yin, H. (2019). Environmental management and labor productivity: The moderating role of quality management. Journal of Environmental Management, 255.

doi:10.1016/j.jenvman.2019.109795

Oware, K. M., \& Mallikarjunappa, T. (2019). Corporate social responsibility investment, third-party assurance and firm performance in India: The moderaing effect of finanial leverage. South Asian Journal of Business Studies, 8(3), 303-324.

Pratono, A. H. (2016). Strategic orientation and information technological turbulence: Contingency. Business Process Management Journal, 22(2), 368-382.

Pratono, A. H. (2018). From social network to firm performance: The mediating effect of trust, selling capability and pricing capability. Management Research Review, 41(6), 680-700.

Pratono, A. H., Ratih, R. V., \& Arshad, D. (2018). Does Entrepreneurial Autonomy Foster SME Growth Under Tehnological Turbulence? The Empirical Evidencce from Indonesia. Journal of Technology in Behavioral Science, 3, 170-178. 